\section{Den Arabiske Rejse og besøget på Sinaihalvøen}

\author{
- belyst ved et udvalg af optegnelser i \\ F.C. von Havens dagbog
}

\section{Affhv. bibliotekar Sven Stouby Pedersen}

$\mathrm{P}$ lanen for den Arabiske Rejse omfattede i sin endelige udformning et besøg på Sinaihalvøen. Dette blev først besluttet i 1760, men ideen med besøget blev fremsat i 1753, da biskoppen afClogher, Robert Clayton udgav "A Journal from Grand Cairo to Mount Sinai. "Heri opfordrede han til en undersøgelse af nogle indskrifter, som han antog stammede fra jødernes ørkenvandring. Stedet, hvor de fandtes, hed ifølge Clayton Gebel el Mokatab, Indskriftsbjerget.

I instruksen for den arabiske Rejse er filologen von Haven og maleren Baurenfeind nævnt som specielt ansvarlige for undersøgelsen af dette sted.

I Konstantinopel traf de rejsende en mand med interesse for Sinairejsen og med den rette position for at hjælpe dem, den britiske ambassadør James Porter. on Haven skriver i sin dagbog 6. August 1761: "Den storbrittaniske Ambassadeur tracteerte som en Chimære, de Inscriptioner, som Biscop Clogher bilder sig ind at skulde findes ved Bierget Sinai, og som var et stykke af vor Commission paa Reysen. Han vidste ingen anden som havde seet disse Inscriptioner, end den eene reysende, som Biscoppen af Clogher anfører. Ingen som kom fra Ægypten og Arabien vidste noget at sige af disse Paaskrifter.
Han giorde sig meere haab om, at vi hos Munkene paa Sinai kunde opdage noget gammelt Manuscript, som vilde alene belønne vor heele Reyse og betale i Henseende til dets værdie, alle dens fortrædeligheder og Omkostninger."

11. august: "Den storbritanniske Ambassadeur havde expres ladet hente Pater Ignatium for at formeere Sælskabet. Denne grækiske Pater var just den lærdeste af alle hans medbrødre i Constantinopel, og just derfor bekiendt hos Ambassadeuren. Han var Archidiaconus, om jeg ikke bedrager mig, og klædet i violette lange Klæder med et ærværdigt Skæg, ligesom den heele grækiske Geistlighed. Han underholdt Venskab og Correspondance med Erkebispen paa bierget Sinai, og hans recommendation var een af dem, som Ambassadeuren ville forskaffe os."

4. september, kort før afrejsen fra Konstantinopel: “Den engelske

Ambassadeur gav os Recommendationsbreve med 1) til Erkebiscopen paa bierget Sinai, og de andre ærværdige fædre i samme Convent 2) til Erkebispen af Bierget Sinai , á parte 3) til den ærværdige fader Christopher fra Macedonien, paa bierget Sinai 4) til en Kiøbmand Sr. Angeli d'Atanasio, en Græker i Cairo 5) til Sr. Niccolo Parebleé, en grækisk Kiøbmand i Rosette 6) til Patriarchen af Alexandrien i Egypten.

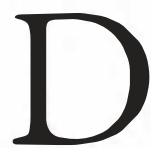
isse Breve vare ikke fra Ambassadeuren selv, men fra andre, som han havde formaaet til at skrive dem. Et var fra en Constantinopolitansk Patriarch, som under den forrige Keyser var bleven exileret til bierget Sinai, og som nyeligen havde vovet sig til hemmeligen at besøge hans familie i Constantinopel, hvor han opholdt sig incognito. Nogle af de andre Breve var fra Pater Ignatius, som ieg har 


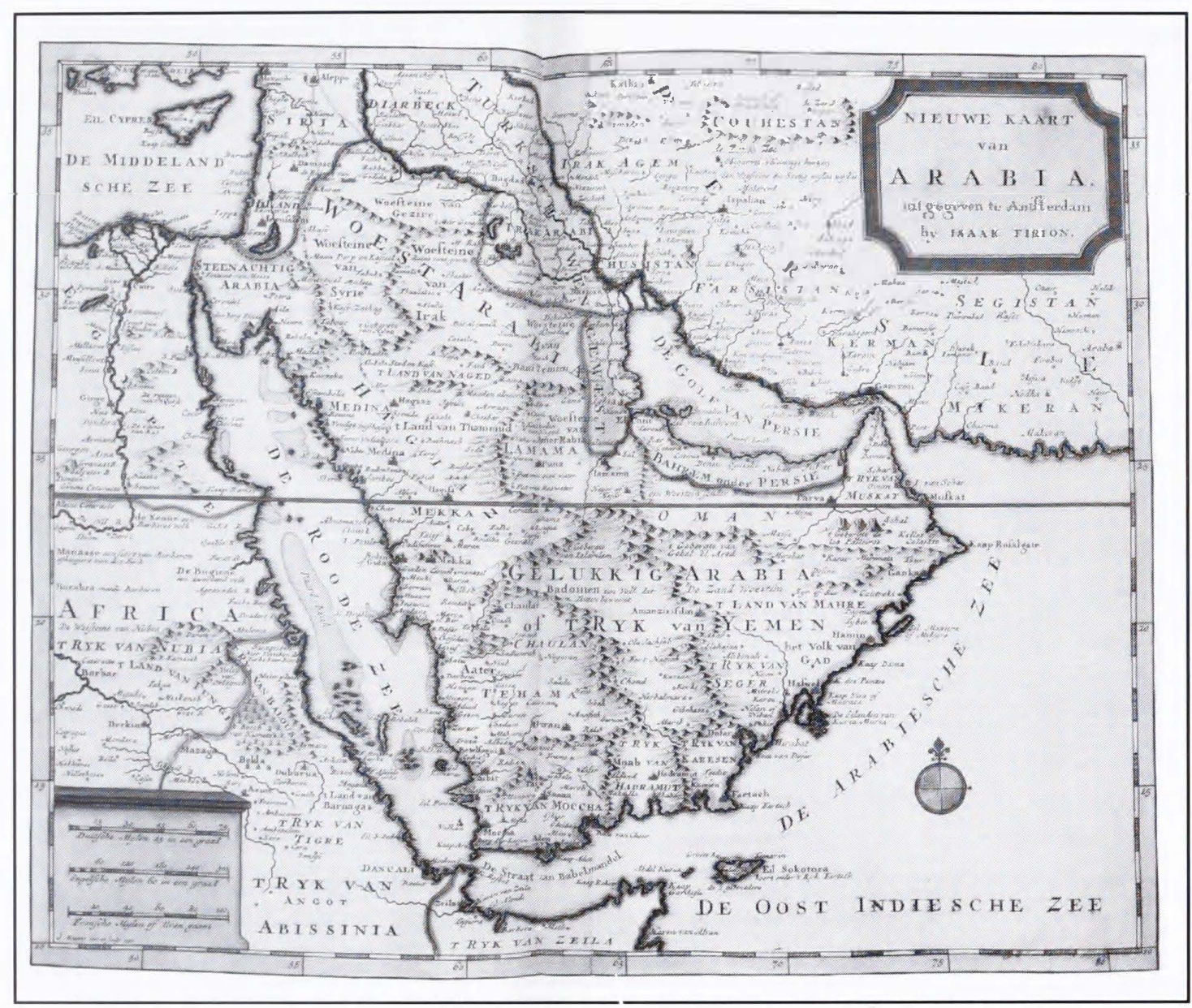

Isaak Tirions kort oner Arabien, 1740) (Foto: "Den Arabiske Rejse 1761-1767. “Udg. $i$ samarbejde med Det Kónglige Bibliotek. 1990).

nævnet oven for under dato af 11 . August."

13. november, kort efter

ankomsten til Kairo, mødte v. Haven ærkebispen af Sinai hos den franske konsul: "Erkebispen fra Bierget Sinai var nys kommen tilbage, efter at han et heelt Aar havde opholdt sig paa bemeldte bierg.

$\mathrm{E}$ rkebispen var en venlig og høflig Mand, og som syntes at smage forskiellen paa at være iblant Franker og imellem streifende Araber.

Man kan let tænke, at jeg ikke glemte at sporge om Inscriptionsbierget, som efter Biscopen af Cloghers Piece, havde giort saa stor Allarm i Europa iblant de Lærde, og opvakt en saa stor Nysgiærighed, at Inscriptioners Copie var bleven en artikel $\mathrm{i}$ vor Instruction.

Jeg forundredes ikke lidet over at høre, at Erkebispen vidste intet deraf, enten fordi dette Bierg ikke Existerede, eller af uvidenhed om dets Existenz. Han havde hørt tale om et Gebal Elmokateb, en dage reyse eller to fra Sinai, men at der var Inscriptioner paa, var ham aldeles ubekiændt.

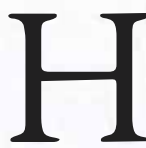

an fortaalte ellers, at Naboelauget af Sinai var bleven formeeret med et stort antal Araber, som havde været i Krig med en anden arabisk Stamme, 
og af den vare blevne drevne paa flugten. Saasom det er en vedtaget Skik, at naar Erkebispen opholder sig paa Bierget Sinai, Closteret maae staae aabent for Araberne, som imidlertiid besøge Munkene flittig for at $æ$ de frit; saa havde Closterets Udgifter derved anseelig liidet denne sidste gang. Erkebispen, som var kied af at holde aaben Tafel for Araberne, havde endelig besluttet at reyse bort. Araberne havde i førstningen holdet ham tilbage.

De havde endelig tilladt ham at reyse bort, men under den Condition, at Closteret efter hans bortreyse ikke skulde tillukkes, og han i en vis tiid skulde betale dem en vis Summe penge. Han havde sagt $\mathrm{dem}$, at han maatte reyse for at samle penge.

Denne Erkebisp staaer ikke under nogen Patriarchs Jurisdiction, men er independent. Closteret skal have anseelige Indkomster, saa fattig som Munkenes udvortes Anseelse ogsaa er."

D. 16. November: “...besøgte vi Erkebiscopen af Bierget Sinai. Han boer udi en Contree, fuld af smaae Stræder og Krinkelkroge, iblant Grækerne, som største deelen boe tilsammen. Indgangen til hans Værelser var ligesaa fuld af omsvøb. Disse detours og smaae Gader ere altid gode og nyttige naar Pøblen i Cairo er opbragt og uroelig. Vor discours var om Sinai og dens Egn. Han gav os de samme beretninger, som jeg oven for har anført, da ieg første gang talte med ham hos den Franske Consul.

$\mathrm{V}$ ed vor afskeed lod han os give Røgelse, og bestænke med Rosen vand. Samme Ære nød vi hos Angeli Athanasio, en Grækisk Kiøbmand, som boer tæt ved Erkebispen, og som vi strax efter besøgte.

Denne Kiøbmand er een af dem, som dirigere handelen paa det røde hav, imellem Cairo og Gidda. Han tilbød sine tienester, naar vi engang paa denne reyse skulde have hans anviisning og recommendationer nødige."

5. januar 1762: "Erkebispen af Sinai havde et par uangenemme tidender fra Bierget Sinai. Den eene var at Araberne havde anholdet 16 grækiske Pillegrime, og tvunget Munkene til at indløse dem med 500 Pattaker. To Pattaker giør en Ungarsk Dukat.

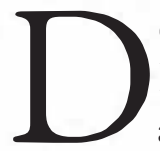
en anden Nyhed var at et andet Partie Araber ved Tor havde angrebet og plyndret de fra Mocha eller Gidda ankommende Skibe. Disse samme tidender fik vi hos Angeli Athanasio, som vi strax derefter besøgte. Man kand let tænke, hvor liden lyst dette gav mig at reyse alene til Bierget Sinai, og desuden om Vinteren, da der er en stor Kuld."

6. januar: "Et brev fra Env. de Gähler af dato d. 17, november 1761. Han siger derudi: Inzwischen ist von Ihro Exc. der Einschluss an Sie Hr. Professor von Haven mir vor einiger Zeit zugekommen, und anmit aufgegeben worden, dass im fall die gelehrte Gesellschaft bereits von Konstantinopel abgereiset seyn möchte, den gesammten Gliedern derselben nahmens Ihro mehr und hochbemeldter Excellenz ich andeuten solte, wie ja ohnehin Sie einige Zeit in Cairo verbleiben dürften, Sie daselbst sich zusammen so lange aufzuhalten hätten, bis von Ihro Ihnen wegen der Fortsetzung dero Bestimmung anderweitige und nähere Befehle würden zukommen, massen Ihre Königl. Mayst. vielleicht in Ihre Absicht auf diese Bestimmung einige Abänderung zu machen, allergnädigst gerufen (geruhen?) dürften. So bald ich darüber einige fernere Belehrung erhalten, werde ich beflissen seyn Eu. Hochedlen solche so fort zu eröfnen." 
$\mathrm{F}$ orsskål, Niebuhr og Baurenfeind havde skrevet til den danske gesandt i Konstantinopel, Gähler, at de frygtede v. Haven ville myrde dem med arsenik. Gähler havde derefter dels, som det fremgår af v. Havens dagbogsoptegnelse, beordret de rejsende foreløbigt at blive i Kairo dels foreslået udenrigsminister Bernstorff at lade v. Haven blive i Ægypten og Syrien mens det øvrige selskab fortsatte rejsen til Sinai og Arabien.

7. januar: "Et svar til H. Env. de Gähler; hvorudi ieg iblant andet sagde, at ieg, om ieg saae leylighed, vilde snart giøre en reyse til B. Sinai, og derefter komme tilbage igien til Cairo; menende at vor ordre at forblive der til videre ordre, ikke indbefattede tillige et forbud at reyse til Sinai, om sligt fandtes beqvemt for resten. Men der blev intet af, formedelst andre aarsager, som siden vil forekomme."

V. Havens brev til Gähler af 7.1. 1762 findes i Rigsarkivet og er trykt i uddrag i Michaelis' Briefwechsel.

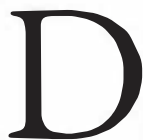
er forekommer intet senere i dagbogen, som for den sidste del af opholdet i Kairo består af kortfattede optegnelser på løse blade, om hvorfor v. Haven ikke rejste til Sinai ved denne lejlighed, men i et brev til Temler af 16. 4. skriver han: Netop på denne tid, begyndelsen af Januar, havde jeg aftalt med en græsk forretningsmand at rejse med næste karavane. Jeg skrev til Gähler, at jeg ikke troede at kunne fritage mig fra at rejse til Sinai og tilbage igen.

Men bagefter mente mine rejsefæller, at vi maatte forstaa ordren bogstaveligt og da særligt maleren simpelthen ikke ville følge mig, måtte jeg afstå fra mit forsæt. Jeg havde dog gerne rejst alene, hvis ikke der var kommet andre årsager til, som jeg gerne vil forbigå i tavshed, indtil vi kommer hjem.

Et brev til Gähler af 23. 4 . indeholder de samme oplysninger. I brevet til Temler beder v. Haven om at få tilsendt Claytons bog. Han fik den aldrig, som det fremgår af en senere bemærkning i dagbogen.

30. juni: "Brv frav. G. i Constantin. af 8 May og fra G. Brnstrff af 3 Febr. 62. Ordre at reyse."

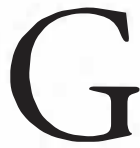
ähler havde nu fået svar fra Bernstorff, som tillod ham, hvis det forekom ham nødvendigt, at skille v. Haven fra de øvrige rejsende, men samtidig gav udtryk for et ønske om at undgå dette.

Gähler beordrede derefter selskabet at rejse videre samlet. De blev dog endnu ca. 2 måneder i Kairo for at vente på, at der blev sluttet fred med araberne, som overfaldt karavanerne.

24. august: "Abdelaziz Chair hos mig. For 35 Aar været ved Gebal Elmocateb etc. Første Notice i Egypt. om dette Biergs Existenz."

I et brev til Gähler af 26. 8. er v. Haven mere udførlig: Indskriftsbjerget viser sig at eksistere. Det er ikke ved den sædvanlige vej til Sinaibjerget og derfor kender munkene og ærkebiskoppen det ikke, da de ikke er så interesserede, at de vil gøre en omvej for at se jødiske mindesmærker. I almindelighed forsømmer, eller rettere ringeagter, grækerne studiet af hebraisk.

n købmand fra Aleppo, Abdelaziz
Chair, er den første, jeg har truffet,
som har set dette bjerg. Tilsyneladende har han været med det samme selskab som den rejsende, hvis beretning er trykt i den engelske biskops bog. Ærkebiskoppen af 


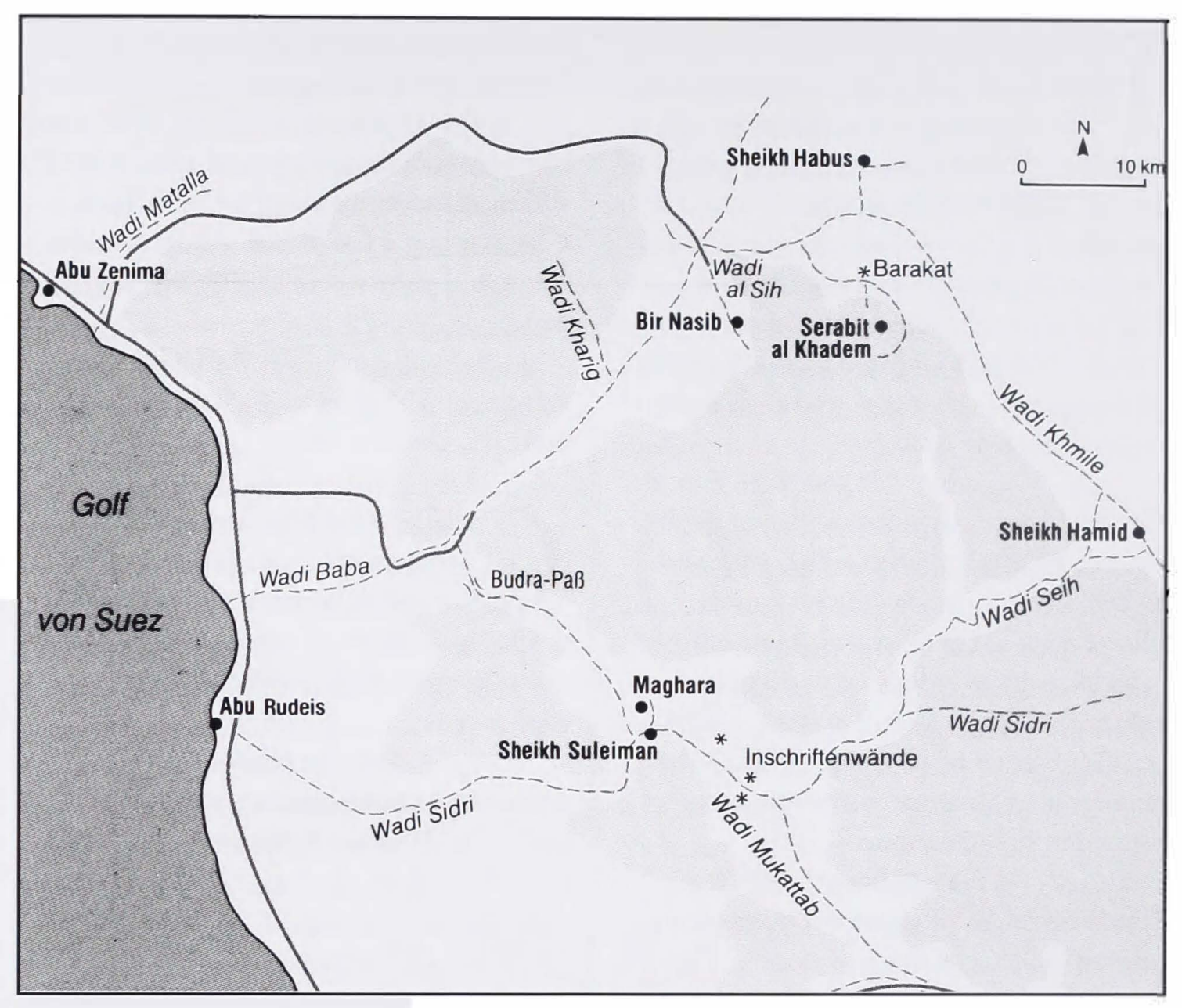

"Inschriftenwände" (i midten af kortet) er stedet, som ekspeditionen skulle have besøgt. "Serabit al K'hadem" (pä kortets øverste del), er lokaliteten hvor ekspeditionen kom til i stedet. (Foto: "Sinai und Rotes Meer").

Sinai siges at være rejst til Konstantinopel.

28. august forlod selskabet Kairo med en karavane til Suez, hvortil de kom d. 30. Undervejs var Baurenfeind blevet så syg, at han ikke kunne rejse videre. Efter at have nævnt de forskellige muligheder, der forelå i denne situation, skriver v. Haven 31. august:

"Vi holdt altsaa for best at reyse saa hastig som mueligt, og at lade den syge med H. I). Kramer blive i Suez til videre. Siden efter fandt Professor Forskål ogsaa for got at blive i Suez. Saa at ingen blev tilovers at giøre Reysen med mig, uden H. L. Niebuhr."

Af sikkerhedsgrunde antog de som førere tre sheiker, der tilhørte hver sin stamme.

4. september: “... blev accorden endelig sluttet paa følgende Conditioner. 1) at vi skulde betale 18 Battaker for hver Dromedarius og 15 for hver Cameel, som vi havde nødig; indbefattet derudi ligeledes 18 
Battak for hver Dromedarius, som

Scheicherne selv rede paa. Vi havde 5

Dromedarier nødig for os selv, 3 for Ara-

berne, og 2 Cameler for vor Bagage og

Betientere. 2) Araberne skulde strax føre to

af os, som ere oven for nævnte, til Tour;

nogen tiid efter skulde een af dem vende tilbage til Suez og afhente de andre tre tilbageblevne, som de skulde føre ligeledes til Tour og til os andre. 3) Dersom nogen af dem ikke skulde kunde eller ikke skulde vilde reyse med, naar saadan een af araberne kom for at afhente dem, saa skulde halvparten af Leyen for hans Dromedarius dog betales. 4) Ingen Araber, uden vore tre Scheicher skulde spise med os undervejs.

$\mathrm{V}$ ore tre Anførere skulde jage alle andre Araber bort, eller selv tractere dem med Mad og Kaffe. 5) Dersom vi havde lyst at blive liggende, 14 eller 20 dage eller længere ved Opskriftsbierget, skulde det staae i vor Magt, og desuden skulde det være ligeledes i vor Magt, at reyse hvorhen og til hvilket sted i den heele Ørken, vi vilde. Det er got at vide, at saa ofte som vi spurgte nogen af vores Araber om Opskrifterne på Bierget, fik vi immer til Svar at der var Ketir, Ketir, Ketir, det er mange, mange, mange, saaledes bemærke de et stort Antal; og naar vi spurgte om der var mange Linier over hverandre, sagde de 30 til 40 og dersom vi spurgde, om det var i heele Længden af Bierget en halv dags reyse, sagde de ja. Da Tractaten var sluttet sagde de os meere, nemlig, at der var mange, mange penge, det er Skatter i Bierget. Det hjalp ikke at vi sagde dem, at vi ikke reyste for at søge forborgne Skatter i Jorden. De begyndte at lade os forstaae, at de troede sligt."

7. september rejste v. Haven og Niebuhr fra Suez med deres ledsagere. 8. september skriver v. Haven om de dale, han så på vestbredden af Suezbugten: "Igennem een af disse to Dale ere formodentlig Israeliterne komne ud fra Ægypten.”

Samme dag: “...den slette Ørken fra Suez til Garendel, og som desuden gaaer Nordlig ud over Suez, synes meget beqvem til at være Ørken Etam ... Num. XXXIII 8 som Israeliterne efter deres overgang over det R. Hav, reyste udi i tre dage. Jeg vover denne formeening, uden at begribe hvor de siden ere reyste hen, og hvor man skal søge Ørken Sin ... ibid v. $11 \& 12$. Thi vi ere siden ingen saa stor Slette kommen igiennem, men lutter maadelige eller smaae eller og snevre Dale."

11. september: "Endelig kom

den dag, som skulde oplyse os om Gebel Elmocattebeh. Vi rede bort paa vore

Dromedarier om Morgenen tilig, med den eene af vore Scheicher, som havde hiemme ved dette Bierg. Thi heromkring boede Børnene af Leghat til hvis Stamme han hørte. Et par andre Araber giorde os Sælskab, i haab at vinde noget; og siden kom flere.

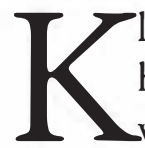
7 ankom vi ved foden af Bierget, hvor vi maatte stige af, og efterlade vore Dromedarier. Vi vare komne igiennem adskillige smaae krumme Dale som paa bægge sider havde en graae, snart og en blaaeagtig Sandsteen. Vi saae Bierget for os, som vi skulde bestige, og saae endnu ingen anden slags Steen, end bemeldte art Sandsteene. Vort Haab begyndte at vanke. Det var ingen Steen som var bequem til Inscriptioner. Vi bestigede Bierget fra $71 / 2$ til $91 / 2$ i to fulde timer. Det var meget steylt. Der gik ingen vey eller fodstie; vi maatte springe af een Steen paa den anden eller klyve op, ved siden af afstyrtelser, eller Præcipicer. Da vi vare komne op, saae vi hist og her noget langt fra os adskillige Steene oprettede, som vi ansaae for Begravelsers 
Tab.XIVI.

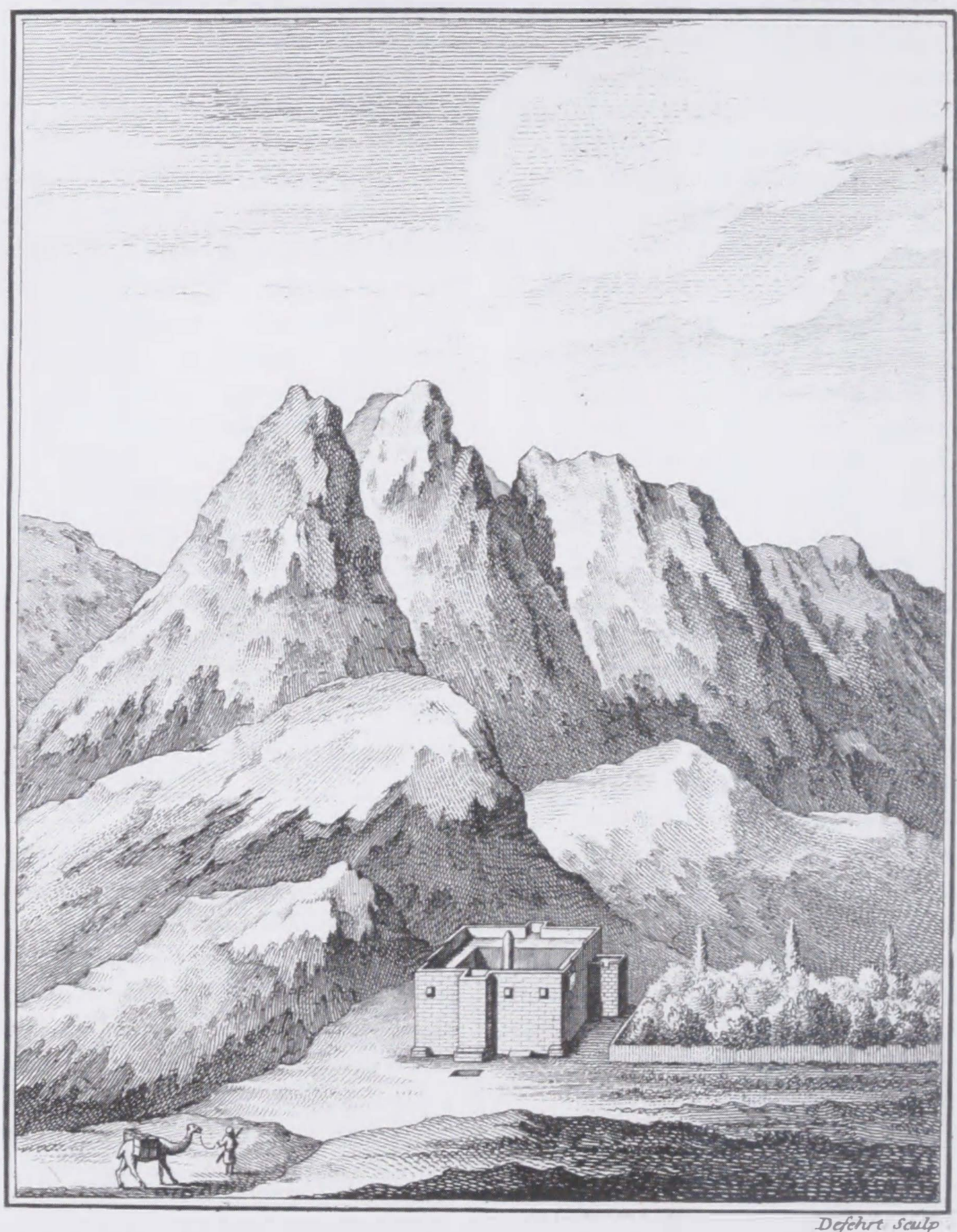

Prospect des Klosters am Berqe Sinai von der Stelle A. auf der Tabelle XIIV.

Skt. Katharina-klosteret ved foden af Sinai-bjerget. (Foto: "Den Arabiske Rejse 1761-1767“. Udg. i samarbejde med Det Kongelige Bibliotek. 1990). 
Mindetegn. Bierget var bredt oven paa, skiøndt ujævnt, og havde maaske en Times gang eller meere, tvert over. Da vi kom bedre frem fandt vi en liden Grotte, som efter al Anseelse var udhuggen i Klippen; og strax derefter en større Grotte, som var 17 til 18 ordentlige Skrit i Længden, 12 til 14 i Breeden, og var af en heel uordentlig figur eller Omkreds. Den blev understøttet af to Pilastres, som vare tilhugne af Klippen selv, og havde maaske hver et par alen i omkreds. Grotten selv var saa laug, at man ikke kunde gaae ræt op derudi; det er at sige, den var 2 3/8 danske Alen høy. Længere frem kom vi til de forhen bemeldte Gravsteene, og vi fandt paa et sted flere tilsammen, end vi langt fra kunde see. Men de vare kastede over ende og sønderbrudte.

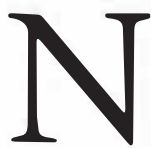
ogle af dem, som endnu stode oprettede, havde Inscriptioner, men Hieroglyfiske. Den største Deel af disse hieroglifer vare af tidens Ælde udslettede eller fordærvede. Saaledes var det beskaffen med alle dem, som vare kuldkastede. Iblant 8 eller 9 Steene, som endnu stode paa fødderne var der neppe fire, som havde en heel reen læselig, eller kiendelig Side af dens Hieroglifer. En Steen kunde være 3 alen høy, $3 / 4$ alen breed paa to sider og $1 / 2$ alen breed paa de to andre Sider. Thi de vare ingen fuldkomne Fïrkanter i Omkredsen. Det var en graaeagtig Sandsteen, som faldt lidet i det brune, eller røde; men saa lidet, at man alene kand kalde den graaeagtig. Jeg veed ikke om den fuldkommen lignede Materien, af Obeliskerne i Rom og Egypten; men Hierogliferne vare af samme art. 4 af disse Steene syntes at være satte i en liden Fiirkant, og at indslutte et Rum af 4 til 5 alen. Men imellem dem og tæt ved dem laae andre sønderbrudte; saa at denne hensigt ikke var fuldkommen kiendelig. Tæt der ved var endnu et par smaae grotter ind under Klippen, men saa opfyldte med Sand og Gruus, at man maatte krybe ind i dem for at besee dem. Den eene af dem var understøttet af en Pilaster af Klippen selv, og havde to smaae huller i dens bageste Væg, nemlig den Væg, som vender lige imod Indgangen. Disse huller eller Nicher vare saa dybe, at de kand have tient til at sætte smaae afguder $\mathrm{i}$, af en alens høyde ongefer.

I blant de sønderbrudte Steene vare i sær to figurer, den eene et Bustum eller Brystbillede, som ansigtet var skamferet paa, formodentligt af araber; og en afgud med tre ansigter, to [til] hver side, og det tredie noget lavere foran; og desuden 2 hænder som sat fast ved Kroppen; men alting slet arbeydet. Det var ongefer saadan en Idol, som ieg lod Hr. Baurenfeind afmale i Alexandrien, efter originalet, som er i den Danske Consuls huus, og som foruden de tre ansigter, var fuldt med Hieroglifer.

Dersom nogen vilde troe at Israeliterne kunde have oprettet disse Gravsteene, og maaske taget den Hieroglifiske Skrivemaade med fra Egypten, i det mindste paa en kort tiid; saa staaer i Veyen de to Figurer, som sikkert Moses ikke har ladet udhugge ved Israeliter, eller for Israeliter; ikke at tale om, at Hierogliferne selv indeholder menniskelige og dyriske figurer.

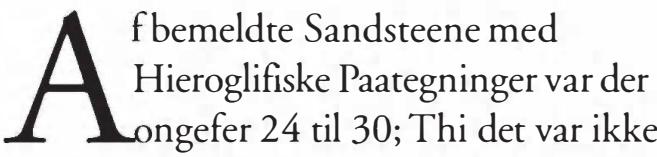
mueligt at tælle dem nøyere, i henseende til at de fleste vare sønderbrudte, og deres Stykker blandede iblant hverandre.

Vi spurgde araberne, hvor de mange Skrifter vare, og saae os om efter 
andre Bierge og Dale for der at opdage de lange og store Inscriptioner. De svarede at dette var alt, og spurgde med forundring, om dette ikke var mange Skrifter? Kort, der var intet meere at see eller opspørge. $\mathrm{Vi}$ maatte spørge vores egne og andre Araber saameget vi vilde, saa forsikrede de os alle at de intet andet Gebel Elmocattebeh i heele Ørken vidste af at sige, end dette. Vi have siden paa den heele Reyse ikke heller kundet opspørge noget andet Bierg, som bedre fortiente dette Navn.

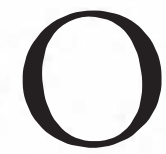
ven paa Bierget var en Scheich Kebir det er, en Stor Scheich, eller een af de fornemmeste, som aftenen tilforne havde spiist med os, og som sagde, at Bierget hørde ham til, og alt hvad der var paa Bierget. Dette var ikke just noget Pralerie. Thi foruden at Araberne ere selv overherrer i Ørken, og der ingen anden Regent erkiende, uden deres egne Scheicher; saa var han een af de øverste Scheiker af Folkene af Leghat. Det kom paa ham an, om han vilde tillade os at skrive eller ikke. For denne tilladelse fordrede han 10 Battakker, foruden en anden Clausul, som han ikke strax vilde rykke ud med. Da han ikke vilde tage imod 4 som vi bød ham, gik vi bort. Underveys sagde os vores egen Scheich sagte i Øret, at dersom den store Scheich og de andre ham tilhørende Araber, skulde have halvparten af de penge, som kom op af Bierget, naar vi skrev, skulde vi have tilladelse at skrive.

Vi loe og svarede ham, at Araberne skulde faae Lov at tage pengene allesammen, nemlig alle dem, som kom op af Jorden, naar vi skrev. Han spurgde om vi da ikke vilde love ham, forud, at der skulde komme penge op? Saasom herpaa ikke var meget at svare, og den store Scheich endnu ikke vilde tage imod den tilbudte Summe; saa bleve ey alene Preliminarierne, men den heele Tractat ophævet.

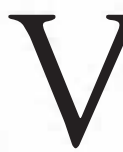

1 gik ned igien, og alle Araberne fulgte os. Vi steeg med besværlig hed ned, og ankom ved vore

Dromedarier ved foden af Bierget Kl. 12. En Time sildigere ankom vi til vor Leyr, hvor den øvrige Caravane var.

Da vore to tilbageblevne

Scheicher hørte, hvor vanskelige vi havde været $i$ at accordere penge, saa spurgte de, hvad sligt skulde betyde? De ventede, at vi i det mindste gav dem et Tusinde Batak eller nogle hundrede af Biergskatten; og saasom vi ikke havde vildet skrive paa ovenmeldte Condition, at give halvparten af Skatten til Araberne, saa mærkede de nok, sagde de, at det var af Ondskab, at vi ikke havde vildet skrive. De forstod nu meget vel, at vi havde beholdt Skrifterne, det er, Inscriptionerne, i hovedet, eller udi Hukommelsen, at vi siden skrev dem, naar vi vare alene, og at Skatten eller pengene, som laae under Bierget, vilde ikke siden feyle at følge os, og komme bag efter os i vort eget Land, naar vi commanderede pengene at marchere.

Det hialp ikke meget, at vi forsikrede, at alt dette var Snak og Overtroe. Den øverste Scheich spurgte mig gandske hidsig, om vi ikke vare af dem, som kunde lade skyerne regne, naar vi vilde. Jeg sagde ham, at han var gal og forrykt i hovedet, og at ieg for denne gang ikke meere vilde snakke med ham.

Om eftermiddagen tiid efter anden fornyedes Accorden, men immer forgiæves.

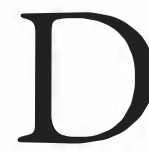
et er sandt, at for en Araber, som hverken forstaar at læse eller skrive, maae det synes meget underligt, at Franker komme saa langt fra, og alene forud 

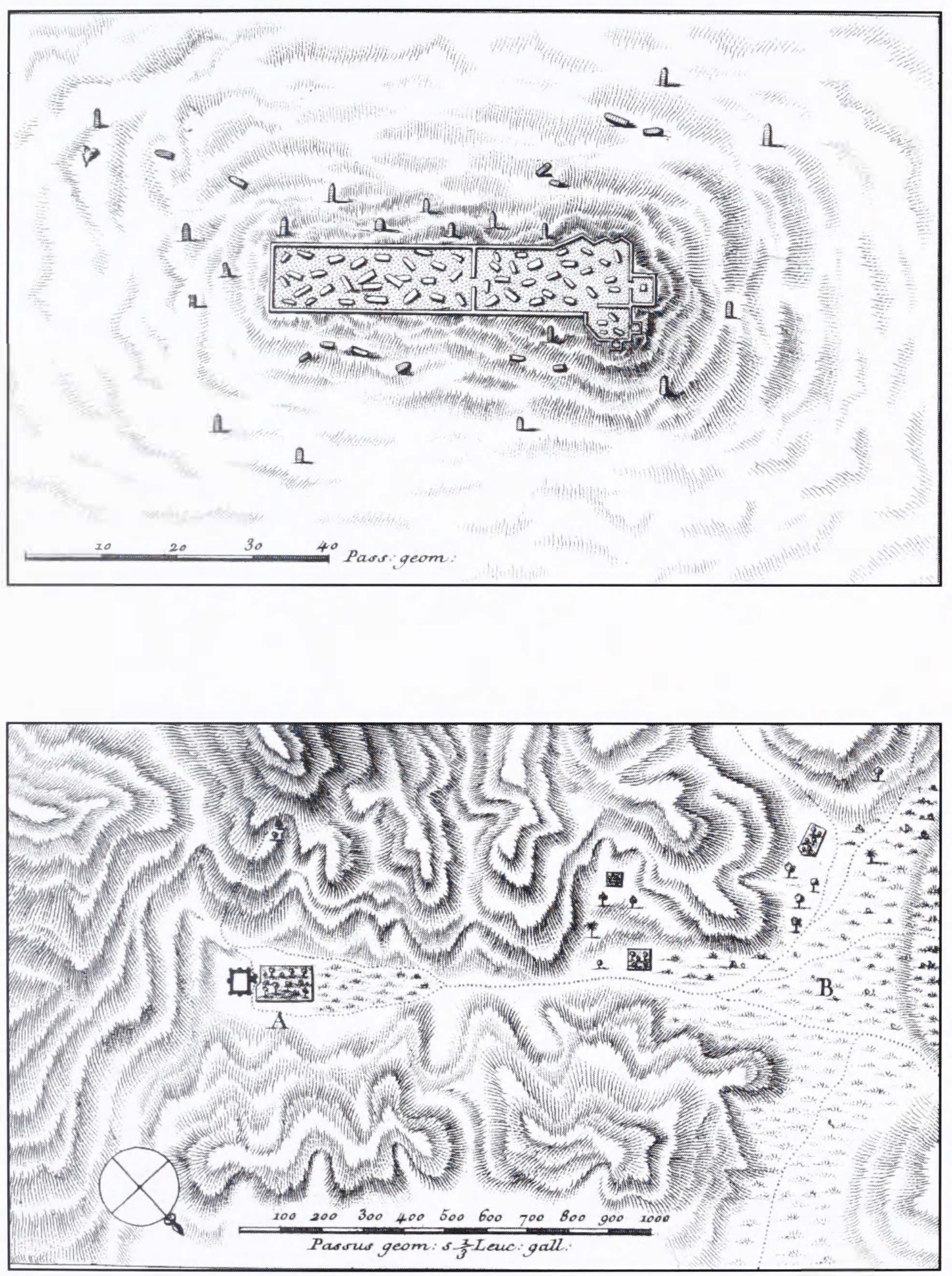

Serabit el Khadem (overst) og Skt. Katharina-klosteret (nederst). (Foto: "Den Arabiske Rejse 1761-1767“. Udg. i samarbejde med Det Kongelige Bibliotek). 
betinge [sig] at de vil blive 14 dage eller 3 Uger ved Gebel Elmocattebeh, hvor der er saa lidet at hente, at een dag er tilstrækkelig til at besee alting. Da de desuden holde Franckerne for Hexemestere, saa er det ikke let, at de kand begribe, hvad slige

Hexemestere vil giøre ved et saa ufrugtbart og magert Bierg, i heele 3 Uger, om det ikke er, at de komme, for at skrive penge op af Jorden, som kand betale dem en saa lang og møysommelig Reyse.

Da de mærkede, at der var ingen penge at hente, foreslog de os at reyse videre. Det var og vores Hensigt. Vi tænkte at faae de Hieroglifiske Paaskrifter ved vor Tilbagekomst, med mindre Vanskelighed. Det blev altsaa besluttet at vi dagen efter skulde begive os paa Veyen til Gebal Musa."

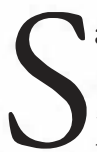
amme dag: "Dersom der skulde altsaa endnu være noget andet Gebel Elmocattebeh, saa maatte det være imellem Hhamam Pharoun og Thor. Dette slutter ieg alene af bemeldte Kiøbmands Relation. Men efter al Anseelse er der intet andet Bierg i Ørken, som er bekiendt under navn af Opskriftsbierget, undtagen det vi have fundet."

Det er der nu alligevel. Det sted Clayton omtaler er mest kendt under navnet Wadi Mokatteb, Indskriftdalen. Vestsiden af dalen kaldes eller kaldtes ialtfald tidligere Djebel Mokatteb, Indskriftbjerget. Indskrifter findes mange steder i Sinai, men her er de i opsigtsvækkende mængde. De mange hundrede indskrifter er nabatæiske, græske, koptiske og arabiske. De stammer fra tiden efter (eller omkring) Kristi fødsel.

14. september: "Vi havde ikkuns een Dags reyse til Closteret, og som vi meente, til Bierget Sinai.

Vi havde den heele dag Gebal
Musa i sigte; som er en stor Biergstrekning, og som paa den vey vi kom fra, nemlig fra vesten viiste sig i en Længde fra Nord til Syd, som vi ikke kunde afsee for andre Bierges skyld.

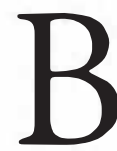
ierget selv er af en blaasort Sandsten; og seer meere liigt en Strekning af nøgne Klipper, end af Bierge. Siden fik [vi] at see at denne Biergstrekning, eller disse Klipper hængde sammen med andre, som gik bag ved dem langt bort i Øster, i Nordost og Sydost. Indgangen til Gebal Musa fra Vesten af, svarede til den fæle anseelse, som disse Klipper havde uden til. Efter nogle faa krumme veye imellem nogle Banker, eller laugere Bierge, gik veyen ind imellem to sønderrevne Bierge i en snever steenagtig Dal.

Efter en god Times March leyrede vi os i denne snevre Dal selv, og af Reysen den følgende Dag saae jeg, at vi havde leyret os midt i Dalen, efter dens Længde. Vi vare nu Klosteret paa Bierget Sinai, som det kaldes, saa nær, at vore Araber lovede os, at vi skulde Morgenen tilig derefter drikke Caffe hos Munkene."

15. september: "Om onsdagen forlod vi vor Natteleyr ved Soelens opgang, og havde endnu en Time af samme slags vey, som vi aftenen forhen havde haft i denne Steendal. Derefter kom vi ud paa en liden Slette eller Plaine, som aabnede sig med en halv Times Breede, og varede i Længden 1 $1 / 4$ Time. Det er ikke omsonst, at ieg anmærker denne Dals Størrelse.

Fra denne af, saa lang som den er, presenterer sig lige i Østen i en anden langt snevrere Dal Closteret, som er indviet til Hellig Cathrine, og hvis Erkebiscop kalder sig Erkebiscop af Bierget Sinai. 


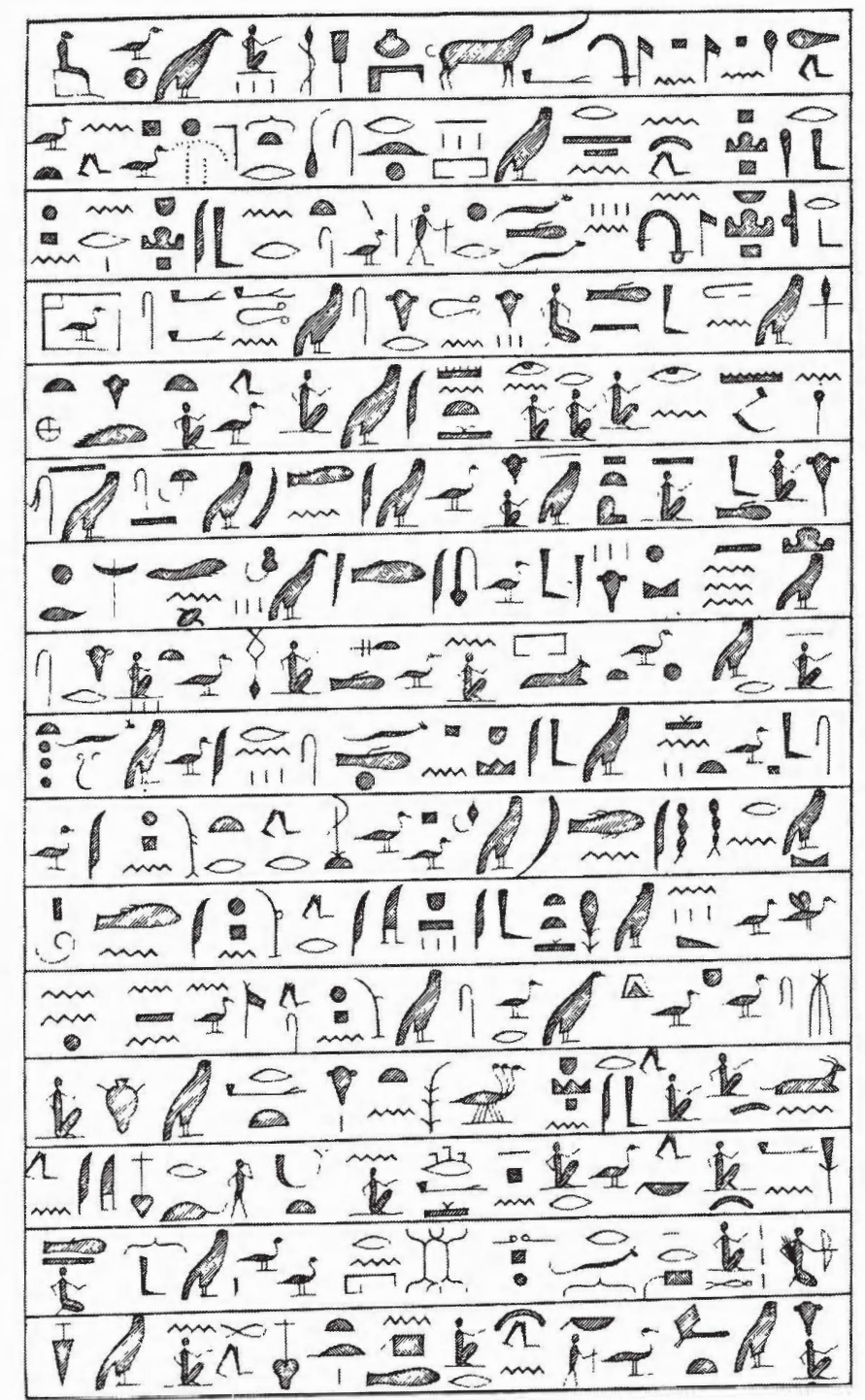

En stele fra Serabitel Khadem. (Foto: "Den Arabiske Rejse 1761-1767“. Udg. i samarbejde med Det Kongelige Bibliotek).

$\mathrm{V}$ 1 kom endelig an ved Closteret selv Kl. $81 \frac{1}{2}$; efterladende vor liden Caravane en $1 / 4$ Time tilbage ved en hauge og ved en Kilde.

Vi havde alene vore tre Gafirer med os. Men saasnart Araberne paa Biergene rundt omkring havde seet fremmede ankomme, forsømte de ikke at begive sig een efter den anden hen til Closteret, for at profitere af de fremmedes Ankomst.
Man maae her vide, at Erkebispen og hans Patres have maattet indgaae med Araberne en Accord, at naar Døren til Closteret bliver aabnet for Pilegrimme eller andre udi Erkebispens Fraværelse, skal Closteret betale til Araberne 200 Ardeb Korn.

Munkene raadslog ikke længe om vort Brev. De gave os det forseglet og ubrudt tilbage ved den samme, som havde 
imodtaget det; med den Undskyldning, at saasom Brevet ikke var fra deres Reis det er deres Erkebiscop, saa kunde de ikke imodtage det. De havde, sagde han, ordre ingen andre Breve at imodtage, end dem som kom fra deres Reis i Cairo. De kunde altsaa ikke tage os ind i Closteret.

Jeg sagde ham, at Brevet var fra Patriarchen Callinichos, som han vel kiendte. Han svarede, at de havde meget vel seet, og kiendt, at Brevet maatte være fra Callinicos, men han igentog forrige undskyldning.

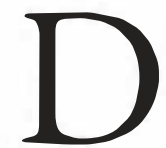
a det ikke var mueligt at komme ind i Closteret; saa bad ieg ham at man i det mindste vilde sælge os for penge nogle Levnetsmidler, saasom næsten al vor Provision var opædt af Araberne. Han svarede, at de vare her i Ørken og at de selv intet havde. Dog vilde han see til, om han fra deres Hauge kunde give os nogle faa Figener og Viindruer. Derpaa gik han bort, og vi fik ham siden ikke meere i tale. Dette Recommendations Brev var os bleven forskaffet $\mathrm{i}$ Constantinopel, ved den Storbrittanniske Ambassadeurs Forsorg. Det var skrevet af Patriarchen Kallinichos, som var bleven relegeret fra Constantinopel ongefer 1756 eller 1755, hen til dette Closter. Han havde levet noget meer end tre Aar i denne Landflygtighed hos de grækiske Munke. Han havde endelig vovet sig, at gaae hemmelig til Constantinopel af Længsel efter hans Familie og Venner. Han vovede dette, saasom det var under den sidst afdøde Tyrkiske Keysers sidste Regierings aar, og under en anden Stor Vizir, at han var bleven afsat og exileret. Men med alt dette opholdt han sig ubekiendt, og var nyelig kommen til Constantinopel, da vi reyste der igiennem.

Da hans Brev var givet os tilbage og blevet unyttigt, saa aabnede ieg det selv, og læste det. Jeg fandt derudi, at Closteret har to Bibliotheker, et gammelt og eet som han kalder det underste Bibliothek. Desuden Codices Membranaceos, ældgamle Codices af Evangelisterne.

Da bemeldte Kallinichos har opholdt sig saa længe i Closteret, saa kand man ikke tvivle paa, at han maa vide hvad der findes. Hans Vidnesbyrd er uforkastelig. Saameget derfor, som det krænkede mig, at vi maatte uden provision eller ringeste Soulagement gaae bort igien; saa fortrød det mig endnu meere, at ieg maatte lade alle disse Codices ubeseet. Det som her hedder det underste Bibliothek kaldes ellers det Nye, og bestaaer formodentlig af trykte grækiske Bøger. Man viser det til alle grækiske Pilegrimme.

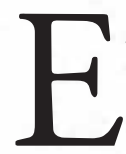

fter en halvtimes tiid blev os over Hauge Muren, som var lige over for Closteret til Vesten, rakt en Kurv fuld ned af Viindruer og Figen.

Arabernespiiste den største deel fra os af denne Present. Vi kom næsten med en tom Kurv tilbage til vor Leyr efter Kl. 12. Det beste vi havde, var klart vand fra Biergene. Jeg har forglemt oven for at anføre at den 12 havde araberne alerede røgt al vor Tobak bort, og tilige borttaget alt Meel og Olie; at den 14 vor Riis ogsaa fik Ende, saa at vi havde intet tilovers uden tørre Tvebakker fra Cairo. Her, sagde de os, var intet at faae, de vidste intet at skaffe; og det forstod sig altsaa af sig selv, at vi maatte vende tilbage igien.

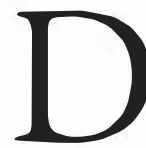
ette var det, som vi nødig vilde. Jeg havde forhen giort den observation, at vi kunde umueligen være ved Bierget Sinai. Closteret laae i en snever Dal, og den Dal, som ieg forhen har givet Maalet paa, er ikke saa stor, 
at en maadelig Armee kunde leyre sig derudi; end sige 600.000 Mand, som Moses havde med sig, og som med Deres Hustruer og Børn maae have giort over 3.000.000 ud. Der var og ingen Kiendetegn til større Dale paa nogen anden Side. Den heele Biergstrekning af Gebal Musa løber korsviis og over tver i mange Arme, og disse Arme indslutte lutter snevre og smaae Dale, hvoraf maaske den er den største, som vi kom igiennem. Det er ikke heller Araberne, som kalde dette Bierg, Bierget Sinai. Det er kuns Munkene selv, og andre reysende, som af dem ere blevne forforte til at troe, at Bierget Sinai laa her. Munkene i sær, maaske for at give Stædet og Pilegrimsreyserne meer Anseelse.

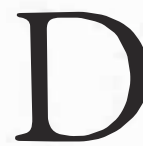
e andre for ikke at have betænkt at Bierget Sinai maae ligge i en stor Dal eller paa en stor Slette, hvor det heele Israelitiske Folkes Mængde har kundet leyre sig rundt omkring. Saa vidt ieg har kundet mærke, kalde Araberne Bierget Sinai, Thur Sina. Vore Araber burde efter vor Accord føre os derhen. De sagde, at det laae endnu to Dages reyse borte, at de frygtede sig for Araberne af Gerarah, som de ikke levede i fred med, og endelig, at vi intet havde at æde. Denne sidste artikel nødte os i sær til at give efter, og det blev besluttet, at vi den følgende Dag skulde vende tilbage.

Udi nabolauget af oftbemeldte grækiske Closter skal og findes den berømte Klippe med de tolv Huller, hvoraf Moses med sin Stav har slaaet Vand ud. Vi have ikke haft den lykke at see den. Aarsagerne til vor Vandheld er let at forstaae af det foregaaende. Jeg tænker at Munkene have fundet denne Steen i deres Naboelaug, ligesom de have fundet Bierget Sinai, og ligesom de have fundet Fodsporet af Muhammeds Dromedar i en Steen oven paa det Bierg, der er dem nærmest.

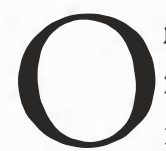
m Tiirsdagen reed H. L. Niebuhr forud med een af vore Scheicher, for at komme op paa Bierget Elmocattebeh, førend vor Ankomst rygtedes, og for at copiere Hierogliferne. Han kunde dog ikke komme saa hemmelig bort, at jo en anden Scheich, som vilde benytte sig af leyligheden, jo sneeg sig efter.

L. Niebuhr kom efter os Kl. 3. og havde med Møye faaet Dessein af 3 Sider af ligesaamange Steene. Han havde maattet betale penge til de to Scheicher, som fulgte ham, førend han kunde faae tilladelse at copiere."

Blandt andet ved hjælp af disse kopier kan det bjerg, som v. Haven og Niebuhr undersøgte, identificeres.

Det kaldes nu Serabit el

Khadem. Her er et ægyptisk tempel, grundlagt i det 12. dynastis tid.

Noter:

Von Havens dagbog, som er på dansk, findes $\mathrm{i}$ Det Kongelige Bibliotek og hans breve, som er på fransk eller tysk, findes $\mathrm{i}$ Rigsarkivet. Uddrag af brevene og en tysk oversættelse af et afsnit af dagbogen er trykt i Literarischer Briefwechsel von Johann David Michaelis. 2. Theil. Leipzig 1795. At det sted med indskrifter, som Clayton omtalte, er Wadi Mokatteb, mens det, som v. Haven og Niebuhr blev ført til, er Serabit el Khadem, er angivet i Georg Gerster: Sinai. Frankfurt 1961. 